Article

\title{
Dietary Folate Intake Is Negatively Associated with Excess Body Weight in Brazilian Graduates and Postgraduates (CUME Project)
}

\author{
Gabriela A. Pereira ${ }^{1}$, Josefina Bressan ${ }^{1}$, Fernando Luiz P. Oliveira ${ }^{2}$, Helena Maria P. Sant'Ana ${ }^{1}$, \\ Adriano M. Pimenta ${ }^{3}$, Lílian L. Lopes ${ }^{1}{ }^{1(D)}$ and Helen Hermana M. Hermsdorff ${ }^{1, *}$ \\ 1 Department of Nutrition and Health, Universidade Federal de Viçosa (UFV), Viçosa, \\ Minas Gerais 36570-900, Brazil; gabiamorimpereira3@gmail.com (G.A.P.); jbrm@ufv.br (J.B.); \\ helena.santana@ufv.br (H.M.P.S.); lilian.lopes@ufv.br (L.L.L.) \\ 2 Department of Statistics, Universidade Federal de Ouro Preto (UFOP), Ouro Preto, Minas Gerais 35400-000, \\ Brazil; fernandoluiz@ufop.edu.br \\ 3 Department of Maternal and Child Nursing and Public Health of the School of Nursing, Universidade \\ Federal de Minas Gerais (UFMG), Belo Horizonte, Minas Gerais 30130-100, Brazil; adrianomp@ufmg.br \\ * Correspondence: helenhermana@ufv.br; Tel.: +55-31-3899-1269; Fax: +55-31-3899-2541
}

Received: 15 January 2019; Accepted: 22 February 2019; Published: 28 February 2019

\begin{abstract}
Folate, vitamin B6, and vitamin B12 intake can be important regulators for obesity development. Thus, we investigated the possible association between the intake of these vitamins and the excess body weight or obesity prevalence in the participants of the Cohort of Universities in Minas Gerais (CUME project). This study analyzed cross-sectional data of 2695 graduates and postgraduates from universities in the state of Minas Gerais (801 men, 1894 women, ages $36.2 \pm 9.4$ ). The first step consisted of collecting data online, and the second step consisted of blood collecting in the subsample living in the city of Viçosa and its region (Minas Gerais). Excess body weight and obesity prevalence were $38.1 \%$ and $10.1 \%$, respectively. Inadequate intake of folate, B6, and B12 were $12,6.3$, and $11.1 \%$, respectively. Beans/lentils and French bread presented the highest contribution to folate intake $(23.45 \%$ and $10.01 \%$, respectively). Those individuals in the third tertile for folate intake $(\geq 511.12 \mu \mathrm{g} / \mathrm{d}$ ) had a lower excess body weight [prevalence ratio (PR): 0.79 , confidence interval (CI): $0.71-0.8]$ and obesity prevalence (PR: $0.60, \mathrm{CI}$ : $0.45-0.78$ ). These associations were maintained when the sample was categorized by sex. In addition, serum folate was positively associated with dietary folate ( $p$ for trend $=0.032$ ) and negatively associated with serum homocysteine ( $p$ for trend $=0.003$ ) in the subsample. Dietary folate intake was negatively associated with excess body weight and obesity in CUME participants, indicating the relevance of this vitamin dietary assessment.
\end{abstract}

Keywords: obesity; folate; B vitamins; body mass index; homocysteine

\section{Introduction}

Obesity is a serious public health problem related to other chronic non-communicable diseases (CNCD) [1,2] in both developed and developing countries [1]. In Brazil, overweight prevalence increased by 26.3 (from $42.6 \%$ to $53.8 \%$ ) and obesity reached a growth of $60 \%$ (from $11.8 \%$ to $18.9 \%$ ) between 2006 and 2016 [3].

Obesity is a polygenic condition that interacts with external factors (e.g., physical inactivity and inadequate eating patterns) [4] and epigenetic changes (e.g., DNA methylation) $[5,6]$. Therefore, several dietary factors may be closely related to adipogenesis regulation through methylation modulation [4]. In this sense, folate, vitamin B6, and vitamin B12 play important roles in the DNA methylation pathway [7] because they participate in the carbon cycle with donations of methyl groups and 
S-adenosylmethionine (SAN) synthesis [8]. In fact, studies have shown an increase in DNA methylation by folate, vitamin B6, and vitamin B12 supplementation $[9,10]$. At the same time, individuals more responsive to diets for weight loss have shown higher levels of global methylation when compared to those less responsive [6]. However, most of the studies related to B vitamins intake and body composition are performed in children [5,11,12].

In this sense, we hypothesized that B-vitamins have negative associations with prevalence of excess body weight and obesity, and we assumed that a detailed approach of the food consumption in Brazilians with high degrees of instruction could generate more reliability in the findings. Due to the scarcity of studies $[13,14]$, especially in adults, our outcomes could be helpful in the implementation of obesity prevention policies as well as subsidies for epigenetic investigations.

Overall, we investigated the association of these B-vitamins with excess body weight and obesity in participants of the Cohort of Universities in Minas Gerais (CUME project).

\section{Materials and Methods}

\subsection{Coorte de Universidades MinEiras: Projeto CUME}

The CUME project is a concurrent open cohort whose objective is to evaluate the impact of the Brazilian dietary pattern and the nutritional transition on NCD in adults $\geq 18$ years old, graduates and postgraduates at the Universidade Federal de Viçosa (UFV), or the Universidade Federal de Minas Gerais (UFMG) -institutions located in the state of Minas Gerais, Brazil. The objective of CUME was to assess the impact of Brazilian dietary pattern and nutrition transition on the occurrence of NCD among graduates and postgraduates of federal higher education institutions located in the state of Minas Gerais, Brazil [15].

The potential volunteers were invited by e-mail and directed to the CUME's virtual page (www.projetocume.com.br). Once they registered, they had access to the first phase of the questionnaire. The first phase contained questions about sociodemographic, anthropometric, lifestyle, and health-related issues. In this study, the following self-reported information was used sex (male/female), age (years), physical activity (yes/no), alcohol consumption (yes/no), smoking (never smoked/former smoker/currently smoke), use of vitamin supplement (yes/no) and television hours per day $(>1 \mathrm{~h} / \leq 1 \mathrm{~h})$. The second phase of the online questionnaire was sent to the volunteers after one week of the first phase response and was composed of a quantitative Food Frequency Questionnaire (FFQ) and 15 questions assessing supplement intake, cooking practices, and dietary habits.

\subsection{Subjects}

Of the 4986 volunteers who answered the baseline CUME questionnaire from March to August 2016, 2695 were included in the present study. The inclusion criteria adopted were: over 20 years of age, completed undergraduate or graduate courses at UFV or UFMG, Brazilian nationality and residency in Brazil over the last year, baseline questionnaire completion, women who reported not being pregnant or that they had not been pregnant in the last year, and individuals who had food consumption between 500 and $4000 \mathrm{kcal}$ per day [16] (Figure 1).

The CUME project was approved by the Human Research Ethics Committee of the educational institutions (opinion number 596.741-0/2013). All participants read the Free and Informed Consent Form and signed their consent (with an online command) before answering the questionnaire. 


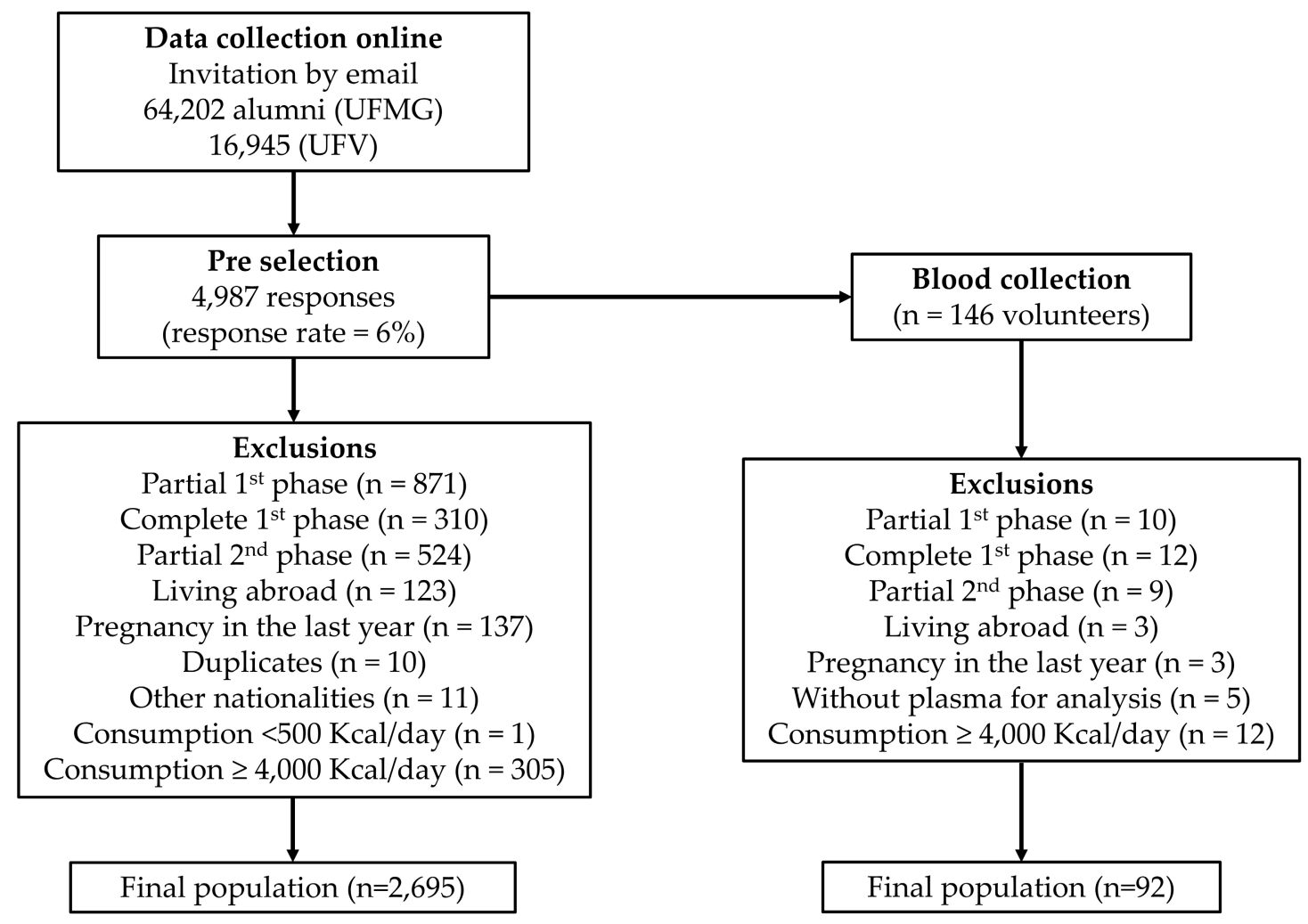

Figure 1. Flowchart of the study $(n=2695)$.

\subsection{Dietary Intake Assessment}

The habitual food consumption was obtained by quantitative FFQ with 144 food items previously validated for the Brazilian population [17] and some added food items that had association with NCDs. Each participant reported the frequency of consumption of a food (daily, weekly, monthly, or annually), the number of times it was consumed (zero to nine or more times), and the portion size appropriate to each food.

Intake of macronutrients and micronutrients was calculated using information from the Brazilian Table of Food Composition [18]; in the absence of information from this, the Table of the Department of Agriculture of the United States was used [19]. The possible insufficient intake of vitamin B6 was defined as lower than $1.1 \mathrm{mg} /$ day for subjects aged 50 years or less and lower than 1.3 and $1.4 \mathrm{mg} /$ day for women and men aged 51 or over. For folic acid and vitamin B12, the possible insufficient intake for all ages was defined as lower than $320 \mu \mathrm{g} /$ day and $2 \mu \mathrm{g} /$ day, respectively [20].

\subsection{Diagnosis of Excess Body Weight and Obesity}

The weight and height self-reported in the online questionnaire were used to calculate the body mass index (BMI) as weight (kilograms) divided by height raised squared $\left(\mathrm{m}^{2}\right)$. The self-reported weight and height were validated with a subsample of participants from the CUME project as described by Miranda et al. [21]. Adult participants were considered as having excess body weight when they presented a BMI $\geq 25 \mathrm{~kg} / \mathrm{m}^{2}$; participants with $B M I \geq 30 \mathrm{~kg} / \mathrm{m}^{2}$ were considered obese [22]. In turn, the elderly were considered as having excess body weight when they presented BMI $\geq 28 \mathrm{~kg} / \mathrm{m}^{2}$ and obese $\geq 30 \mathrm{~kg} / \mathrm{m}^{2}$ [23].

\subsection{Biological Material Collection}

Participants who had completed the questionnaire online and currently live in the city of Viçosa and region were invited by e-mail to participate in blood sampling (Figure 1). If the volunteer accepted, they were at the Laboratory of Energy Metabolism and Body Composition (LAMECC-DNS/UFV) in 
$12 \mathrm{~h}$-fasting on a previously scheduled day. Blood samples were collected by a nursing professional and immediately taken to the Laboratory of Clinical Analysis (LAC-DNS/UFV), where they were centrifuged (3500 rpm, $5{ }^{\circ} \mathrm{C}, 15 \mathrm{~min}$ ), aliquoted, and stored at $-80{ }^{\circ} \mathrm{C}$. The serum folic acid and homocysteine concentrations were measured from $2 \mathrm{~mL}$ of serum of each volunteer using the Chemiluminescence method.

A total of 146 volunteers participated in biological material collection, of which 110 had previously completed all phases of the baseline questionnaire and had their plasma collected for homocysteine and folate analysis. Of these, 92 met all the inclusion criteria and were selected for the present study (Figure 1).

The Human Research Ethics Committees of the UFV and UFMG approved the collection phase (opinion no. 1,588,799/2016), and all the participants agreed and signed a Free and Informed Consent Form regarding blood collection.

\subsection{Statistical Analysis}

The database was elaborated in SPSS $^{\circledR}$ software version 20.0 (SPSS Inc., Chicago, IL, USA). All statistical analyses were performed in SPSS ${ }^{\circledR}$ version 20.0 and STATA ${ }^{\circledR}$ version 13.0, adopting a statistical significance of $5 \%(\alpha)$.

To control the effect of caloric intake on the relation of vitamin consumption and the occurrence of excess body weight and obesity, consumption variables were adjusted for total caloric intake by the residual method [24].

Sociodemographic characteristics among individuals with and without excess body weight were compared using the Pearson's chi-square test. The relative contribution of each food to the daily intake of folate, vitamin B6, and vitamin B12 was obtained by calculating the ratio between each individual food nutrient content and the total nutrient amount supplied by all foods [25]. Food items were sorted in descending order according to their relative contribution averages for each nutrient [26]. Those items contributing to at least $1 \%$ of the total intake for each nutrient were presented in this study [27].

The relation between folate intake, homocysteine, and serum folate was established using multiple linear regression models adjusted for sex and age.

To assess the association between B vitamins and excessive weight, participants were categorized according to vitamin consumption tertiles. Poisson regression was used to estimate the prevalence ratio (PR) and its $95 \%$ confidence interval (CI, 95\%) of excess body weight and obesity in the total sample, as well as for the male group and for excess body weight in the female group, using the first tertile of consumption of vitamins as a reference. As the obesity prevalence in the female sample was less than $10 \%$, the odds ratio (OR) was estimated using logistic regression with the first vitamin consumption tertile as a reference.

\section{Results}

Of the 2695 volunteers who participated in this study, 70.3\% were females and age mean was $36.2( \pm 9.4)$. Excess body weight prevalence was $38.1 \%$ in our sample, in which $10.1 \%$ were obese and $28 \%$ were overweight. Women and men were $22.8 \%$ and $40.6 \%$ overweight and $8.7 \%$ and $13.2 \%$ obesity, respectively. In addition, participants with excess body weight were predominantly aged $\geq 40$ years, males, married, smokers and ex-smokers, alcohol drinkers, and watchers of television $(>1 \mathrm{~h} / \mathrm{d})$ compared to participants without excess body weight (Table 1). 
Table 1. Socio-demographic characteristics according to the presence or not of excess body weight ${ }^{\dagger}$ of the CUME project participants $(n=2695)$.

\begin{tabular}{|c|c|c|c|}
\hline \multirow[t]{2}{*}{ Characteristics $[n(\%)]$} & $\begin{array}{c}\text { Without Excess } \\
\text { Body Weight }\end{array}$ & $\begin{array}{c}\text { With Excess Body } \\
\text { Weight }\end{array}$ & \multirow[t]{2}{*}{$p$ Value * } \\
\hline & $n=1667$ & $n=1028$ & \\
\hline \multicolumn{4}{|l|}{ Age } \\
\hline$<40$ years & $1278(76.7)$ & $644(62.6)$ & $<0.001$ \\
\hline$\geq 40$ years & $389(23.3)$ & $384(37.4)$ & \\
\hline \multicolumn{4}{|l|}{ Sex } \\
\hline Male & $370(22.2)$ & $431(41.9)$ & $<0.001$ \\
\hline Female & $1297(77.8)$ & $597(58.1)$ & \\
\hline \multicolumn{4}{|l|}{ Civil status } \\
\hline Married or stable union & $775(46.5)$ & $557(54.2)$ & $<0.001$ \\
\hline Single, separated/divorced, widower & $892(53.5)$ & $471(45.8)$ & \\
\hline \multicolumn{4}{|l|}{ Practice of physical activity } \\
\hline Yes & $1306(78.3)$ & $744(72.4)$ & $<0.001$ \\
\hline No & $361(21.7)$ & $284(27.6)$ & \\
\hline \multicolumn{4}{|l|}{ Consumption of alcoholic beverage } \\
\hline Yes & $1207(72.4)$ & $781(76.0)$ & 0.041 \\
\hline No & $460(27.6)$ & $247(24.0)$ & \\
\hline \multicolumn{4}{|l|}{ Use of vitamin supplement } \\
\hline Yes & $496(30.0)$ & $258(25.3)$ & 0.009 \\
\hline No & $1155(70.0)$ & $760(74.7)$ & \\
\hline \multicolumn{4}{|l|}{ Smoking } \\
\hline Yes & $292(17.5)$ & $252(24.5)$ & $<0.001$ \\
\hline No & $1375(82.5)$ & $776(75.5)$ & \\
\hline \multicolumn{4}{|l|}{ TV time per day } \\
\hline$\leq 1 \mathrm{~h}$ & 1015 (60.9) & $513(49.9)$ & $<0.001$ \\
\hline$>1 \mathrm{~h}$ & $651(39.1)$ & $515(50.1)$ & \\
\hline
\end{tabular}

\subsection{Consumption of B Vitamins and Contributing Foods}

In relation to the consumption of $\mathrm{B}$ vitamins, $12 \%$ of the participants presented a possible insufficient intake for folate, $6.3 \%$ for vitamin B6, and $11.1 \%$ for vitamin B12, according to their Estimate Average Requirement (EAR) (IOM, 2002). Of the total food, 23 foods contributed to folate consumption, 29 for vitamin B6 consumption, and 20 for vitamin B12. In addition, beans/lentils (23.45\%), French bread $(10.01 \%)$, and papaya (3.93\%) mostly contributed to folate consumption (Table 2), while banana $(11.08 \%)$, pork (5.14\%), and beef $(4.67 \%)$ mostly contributed to B6 consumption, and cheese $(13.98 \%)$, beef $(11.97 \%)$, and fish $(8.03 \%)$ to vitamin $\mathrm{B} 12$.

Table 2. Contribution (\%) of food items to the dietary folate, vitamin B6, and vitamin B12 of the CUME project participants $(n=2695)$.

\begin{tabular}{|c|c|c|c|c|c|}
\hline \multicolumn{2}{|l|}{ Folate } & \multicolumn{2}{|c|}{ Vitamin B6 } & \multicolumn{2}{|l|}{ Vitamin B12 } \\
\hline Food & $(\%)$ & Food & $(\%)$ & Food & $(\%)$ \\
\hline Beans/Lentil & 23.45 & Banana & 11.08 & Cheese & 13.98 \\
\hline French Bread & 10.01 & Pork & 5.14 & Beef & 11.97 \\
\hline Papaya & 3.93 & Beef & 4.67 & Fish & 8.03 \\
\hline Brown bread & 3.46 & Loaf bread & 4.65 & Sardine/Tuna fish & 6.85 \\
\hline Loaf bread & 3.43 & Beans/Lentil & 4.35 & Whole milk & 6.66 \\
\hline Cheese bread & 3.27 & Cooked potato & 4.22 & Skimmed milk & 6.14 \\
\hline Avocado & 3.08 & Natural juice & 3.36 & Egg & 5.71 \\
\hline Banana & 2.96 & Orange/Tangerine & 3.32 & Salmon & 4.46 \\
\hline Orange/Tangerine & 2.79 & Avocado & 2.56 & Fried snacks & 4.28 \\
\hline Cress/Cabbage/Arugula/Spinach & 2.57 & Salmon & 2.42 & Nonfat yogurt & 3.92 \\
\hline Sweet bread & 2.05 & Cassava/Yam & 2.26 & Yogurt & 3.23 \\
\hline Egg & 1.89 & Beer & 2.25 & Viscera & 2.75 \\
\hline Tomato & 1.62 & Brown bread & 2.04 & Semi-skimmed milk & 2.74 \\
\hline
\end{tabular}


Table 2. Cont

\begin{tabular}{|c|c|c|c|c|c|}
\hline \multicolumn{2}{|l|}{ Folate } & \multicolumn{2}{|l|}{ Vitamin B6 } & \multicolumn{2}{|l|}{ Vitamin B12 } \\
\hline Food & $(\%)$ & Food & $(\%)$ & Food & $(\%)$ \\
\hline Pizza & 1.53 & French Bread & 2.01 & Pork & 2.74 \\
\hline Lettuce/Chard & 1.43 & Chocolate powder & 1.91 & Pizza & 2.22 \\
\hline Chickpeas & 1.40 & Chili & 1.86 & $\begin{array}{l}\text { Milk chocolate/Bonbon/Chocolate } \\
\text { truffle }\end{array}$ & 1.56 \\
\hline Guava & 1.28 & Skimmed milk & 1.84 & Franfurter/Sousage & 1.58 \\
\hline Hot dog/Hamburger & 1.19 & Whole rice & 1.71 & Morning cereal & 1.38 \\
\hline Morning cereal & 1.17 & Whole milk & 1.57 & Hot dog/Hamburger & 1.29 \\
\hline Beet & 1.16 & Tomato & 1.46 & Ice cream & 1.00 \\
\hline Cassava/Yam & 1.16 & Peanut/Chestnuts/Walnuts & 1.38 & - & - \\
\hline Peanut/Chestnuts/Walnuts & 1.10 & Apple & 1.32 & - & - \\
\hline Beer & 1.04 & Egg & 1.31 & - & - \\
\hline- & - & Fish & 1.24 & - & - \\
\hline- & - & Papaya & 1.22 & - & - \\
\hline- & - & Pizza & 1.11 & - & - \\
\hline- & - & Fried snacks & 1.06 & - & - \\
\hline- & - & Lettuce/Chard & 1.03 & - & - \\
\hline- & - & Morning cereal & 1.00 & - & - \\
\hline
\end{tabular}

\subsection{Folate Intake and Excess Body Weigh}

Interestingly, participants included in the second and third tertiles of folate consumption intake had lower excess body weight and obesity occurrences regardless of confounding factors. The participants in the last tertile of vitamin B6 intake also had lower excess body weight or obesity in the adjusted model by sex and age. However, this association lost significance when adjusting for the other variables such as sex, age, alcohol consumption, physical activity, smoking, television hours per day, use of vitamin supplement, and daily caloric intake (Table 3). Furthermore, when categorizing the sample by gender, the associations remained significant for excess body weight and obesity. The participants in the second and third tertiles of folate consumption had lower excess body weight or obesity (Table 4). These associations did not lose significance when adjusted for age (Model 1), physical activity, smoking, television hours per day, use of vitamin supplement, and daily caloric intake (Model 2).

Table 3. Prevalence ratio (PR) for excess body weight * and obesity ** according to dietary folate, vitamin B6, and vitamin B12 of the CUME participants $(n=2695)$.

\begin{tabular}{|c|c|c|c|c|}
\hline & \multicolumn{2}{|c|}{ Model 1} & \multicolumn{2}{|c|}{ Model 2} \\
\hline & RP (IC95\%) & $p$ Value & RP (IC95\%) & $p$ Value \\
\hline \multicolumn{5}{|l|}{ Excess body weight ${ }^{\dagger}$} \\
\hline \multicolumn{5}{|l|}{ Folate $(\mu \mathrm{g} / \mathrm{d})$} \\
\hline $\mathrm{T} 1<407.95$ & 1.0 & & 1.0 & \\
\hline T2 407.95-511.12 & $0.75(0.67-0.84)$ & $<0.001$ & $0.77(0.69-0.87)$ & $<0.001$ \\
\hline $\mathrm{T} 3>511.12$ & $0.76(0.68-0.85)$ & $<0.001$ & $0.79(0.71-0.89)$ & $<0.001$ \\
\hline \multicolumn{5}{|l|}{ Vitamin B6 (mg/d) } \\
\hline $\mathrm{T} 1<1.50$ & 1.0 & & 1.0 & \\
\hline T2 1.50-1.79 & $0.94(0.84-1.05)$ & 0.332 & $0.99(0.89-1.12)$ & 0.999 \\
\hline $\mathrm{T} 3>1.79$ & $0.88(0.78-0.98)$ & 0.032 & $0.91(0.81-1.02)$ & 0.112 \\
\hline \multicolumn{5}{|l|}{ Vitamin B12 $(\mu \mathrm{g} / \mathrm{d})$} \\
\hline $\mathrm{T} 1<3.16$ & 1.0 & & 1.0 & \\
\hline T2 3.16-4.50 & $0.98(0.88-1.11)$ & 0.860 & $1.03(0.91-1.16)$ & 0.570 \\
\hline $\mathrm{T} 3>4.50$ & $1.00(0.90-1.13)$ & 0.878 & $1.05(0.93-1.18)$ & 0.385 \\
\hline \multicolumn{5}{|l|}{ Obesity $^{+}$} \\
\hline \multicolumn{5}{|l|}{ Folate $(\mu \mathrm{g} / \mathrm{d})$} \\
\hline $\mathrm{T} 1<407.95$ & 1.0 & & 1.0 & \\
\hline T2 407.95-511.12 & $0.57(0.43-0.75)$ & $<0.001$ & $0.61(0.46-0.81)$ & 0.001 \\
\hline $\mathrm{T} 3>511.12$ & $0.58(0.45-0.76)$ & $<0.001$ & $0.60(0.45-0.78)$ & $<0.001$ \\
\hline
\end{tabular}


Table 3. Cont.

\begin{tabular}{ccccc}
\hline & \multicolumn{2}{c}{ Model 1 } & \multicolumn{2}{c}{ Model 2 } \\
\cline { 2 - 5 } & RP (IC95\%) & $\boldsymbol{p}$ Value & RP (IC95\%) & $\boldsymbol{p}$ Value \\
\hline Vitamin B6 $(\mathrm{mg} / \mathrm{d})$ & & & & \\
T1 $<1.50$ & 1.0 & & 1.0 & \\
T2 $1.50-1.79$ & $0.88(0.67-1.16)$ & 0.382 & $1.07(0.81-1.40)$ & 0.608 \\
T3 $>1.79$ & $0.75(0.57-0.99)$ & 0.043 & $0.86(0.65-1.13)$ & 0.286 \\
T1 $<3.16$ & & & & \\
T2 3.16-4.50 & 1.0 & & 1.0 & 0.122 \\
T3 $>4.50$ & $1.00(0.78-1.38)$ & 0.761 & $1.25(0.94-1.66)$ & 0.261 \\
\hline
\end{tabular}

* Excess body weight: BMI $\geq 25 \mathrm{~kg} / \mathrm{m}^{2}$ (WHO, 1998), BMI $\geq 28 \mathrm{~kg} / \mathrm{m}^{2}$ (OPAS, 2002) for adults and elderly respectively. ${ }^{* *}$ Obesity: BMI $\geq 30 \mathrm{~kg} / \mathrm{m}^{2}$ (WHO, 1998; OPAS, 2002). ${ }^{+}$Sample represents 1028 participants with excess body weight and 271 with obesity. Poisson regression Model 1: adjusted for age and sex. Poisson regression Model 2: adjusted for sex (female/male), age (years), alcohol consumption (yes/no), physical activity (yes/no), smoking (never smoked/former smoker/currently smoke), television hours per day ( $>1 \mathrm{~h} / \leq 1 \mathrm{~h}$ ), use of vitamin supplement (yes/no), and daily caloric intake.

Table 4. Prevalence ratio (PR) or odds ratio (OR) for excess body weight * and obesity ** for males and females according to tertiles of folate intake $(\mu \mathrm{g} / \mathrm{d})$ of the CUME project participants $(n=2695)$.

\begin{tabular}{|c|c|c|c|c|}
\hline & \multicolumn{2}{|c|}{ Model 1} & \multicolumn{2}{|c|}{ Model 2} \\
\hline & RP (IC95\%) & $p$ Value & RP (IC95\%) & $p$ Value \\
\hline \multicolumn{5}{|l|}{ Excess body weight ${ }^{\dagger}$} \\
\hline \multicolumn{5}{|l|}{ Male } \\
\hline $\mathrm{T} 1<453.51$ & 1.0 & & 1.0 & \\
\hline T2 453.51-585.39 & $0.84(0.72-0.98)$ & 0.033 & $0.84(0.71-0.98)$ & 0.032 \\
\hline $\mathrm{T} 3>585.39$ & $0.83(0.71-0.97)$ & 0.024 & $0.84(0.72-0.98)$ & 0.036 \\
\hline \multicolumn{5}{|l|}{ Female } \\
\hline $\mathrm{T} 1<388.78$ & 1.0 & & 1.0 & \\
\hline T2 388.78-480.99 & $0.73(0.62-0.85)$ & $<0.001$ & $0.78(0.67-0.92)$ & 0.003 \\
\hline $\mathrm{T} 3>480.99$ & $0.70(0.60-0.82)$ & $<0.001$ & $0.74(0.63-0.87)$ & $<0.001$ \\
\hline \multicolumn{5}{|l|}{ Obesity $^{\dagger}$} \\
\hline \multicolumn{5}{|l|}{ Male } \\
\hline $\mathrm{T} 1<453.51$ & 1.0 & & 1.0 & \\
\hline T2 453.51-585.39 & $0.58(0.38-0.88)$ & 0.012 & $0.56(0.36-0.88)$ & 0.012 \\
\hline $\mathrm{T} 3>585.39$ & $0.51(0.33-0.80)$ & 0.003 & $0.50(0.32-0.79)$ & 0.003 \\
\hline \multicolumn{5}{|l|}{ Female } \\
\hline $\mathrm{T} 1<388.78$ & 1.0 & & 1.0 & \\
\hline T2 388.78-480.99 & $0.65(0.44-0.95)$ & 0.030 & $0.78(0.52-1.71)$ & 0.234 \\
\hline $\mathrm{T} 3>480.99$ & $0.55(0.36-0.82)$ & 0.003 & $0.57(0.37-0.86)$ & 0.009 \\
\hline
\end{tabular}

* Excess body weight: BMI $\geq 25 \mathrm{~kg} / \mathrm{m}^{2}$ (WHO, 1998), BMI $\geq 28 \mathrm{~kg} / \mathrm{m}^{2}$ (OPAS, 2002) for adults and elderly, respectively. ${ }^{* *}$ Obesity: BMI $\geq 30 \mathrm{~kg} / \mathrm{m}^{2}$ (WHO, 1998; OPAS, 2002). ${ }^{+}$Excess body weight sample composed of 431 people in the male group and 597 in the female group; for the sample with obesity, 106 in the male group and 165 in the female group. Poisson or logistic (obesity females) regression Model 1: adjusted for age (years). OR was performed for the female group due to a prevalence of obesity less than $10 \%$. Poisson or logistic (obesity females) regression Model 2: adjusted for age (years), alcohol consumption (yes/no), physical activity (yes/no), smoking (never smoked/former smoker/currently smoke), television hours per day $(>1 \mathrm{~h} / \leq 1 \mathrm{~h}$ ), use of vitamin supplement (yes/no), and daily caloric intake. OR was performed for the female group due to a prevalence of obesity less than $10 \%$.

\subsection{Serum Folate, Dietary Folate and Homocysteine in Subsample}

In the subsample participants, serum folate was positively associated with a dietary folate ( $p$ trend $=0.032$ ) and negatively associated with lower serum homocysteine concentrations ( $p$ of trend $=0.003$ ) regardless of sex and age (Figure 2). 

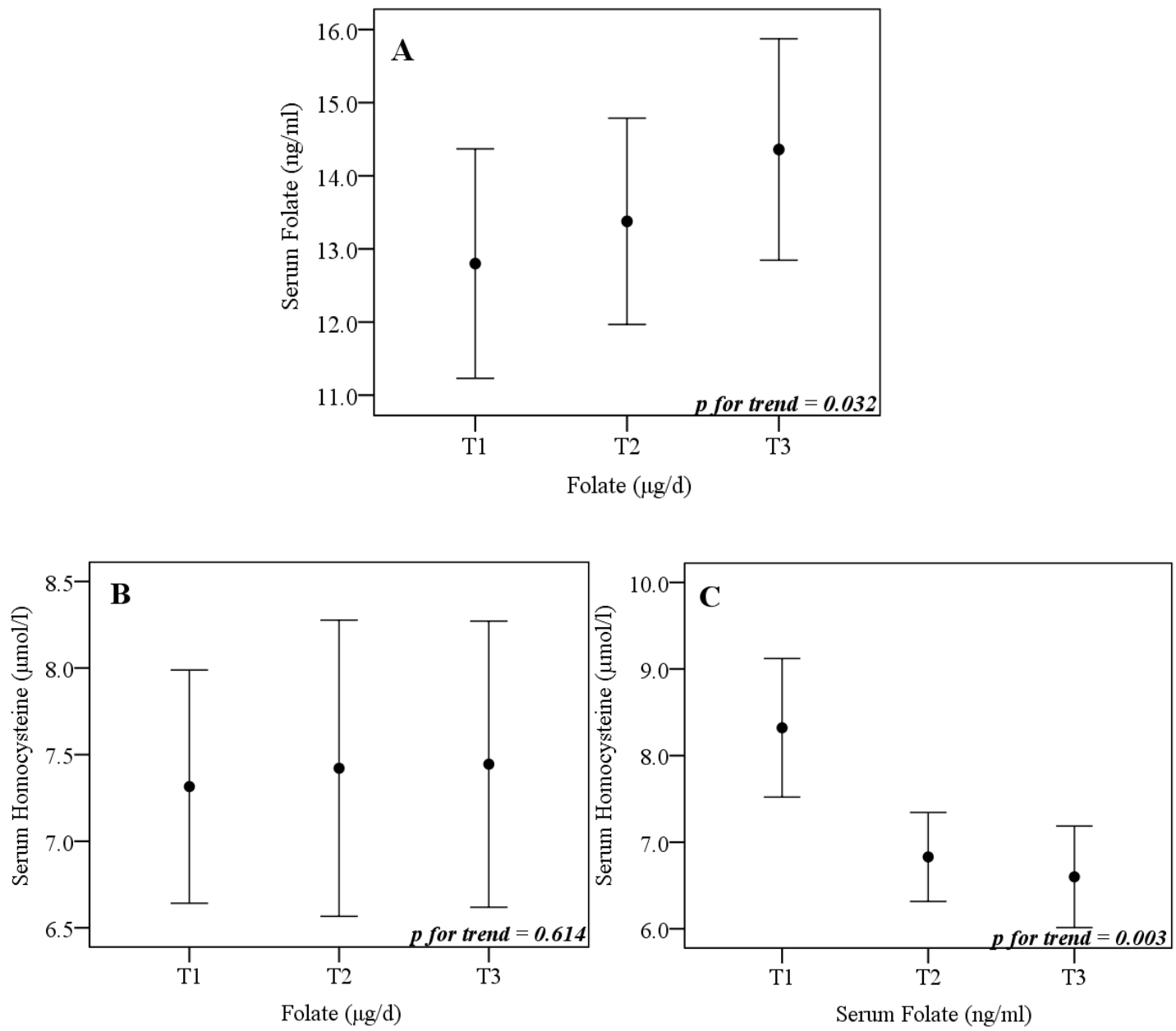

Figure 2. Serum folate and homocysteine values (A and B) according to tertiles of folate intake ( $n=92)$, and homocysteine values $(\mathbf{C})$ according to tertiles of serum folate in participants of the face-to-face collect of the CUME project $(n=110)$. $p$ for trend in the multiple linear regression model adjusted for sex (male or female) and age (years). A and B: T1 < 414.64; T2 414.64-524.22; T3 > 524.22 $\mu \mathrm{g} / \mathrm{d}$. C: $\mathrm{T} 1<11.32 ; \mathrm{T} 2$ 11.32-15.17; T3 > $15.17 \mathrm{ng} / \mathrm{mL}$.

\section{Discussion}

In the present study, we observed an inverse association between folate intake and the prevalence of excess body weight and obesity. Our findings are corroborated with a previous cross-sectional study with 3767 participants from the NHANES program (National Health and Nutrition Examination Survey). This study found a trend of decreased folate intake with increased BMI [13]. Another study had shown a negative association of dietary folate with BMI $[5,11]$ and waist circumference [12] in children as well as negative association between serum folate and BMI in adults $[13,28]$. The mechanisms that explain the relation between folate metabolism and obesity are still limited [13]. Obesity and related disorders have been associated with epigenetic changes such as aberrant DNA methylation patterns for genes involved in metabolic regulation and global DNA hypomethylation $[1,4,6]$. Studies have shown significant associations between serum folate, DNA methylation, BMI, and body fat percentage [29], and a higher folate intake from fortified foods with higher DNA methylation measured by LINE 1 in white cells [30]. Altogether, these findings support the hypothesis that higher folate intake could act as a protective factor against obesity by epigenetic mechanisms.

In this study, serum folate was negatively associated with serum homocysteine and positively associated with dietary folate, although no significant association between serum homocysteine and 
folate intake was found. Homocysteine, an intermediate in the one carbon pathway, is synthesized from methionine having, as main substrates, the SAM and S-adenosyl homocysteine (SAH). Since homocysteine and SAH interconvert by hydrolysis reaction, an increase in the serum concentrations may lead to the inhibition of enzyme DNA methyltransferase, which acts by transferring groups of a one carbon from SAM to DNA [8]. In fact, increased homocysteine concentrations are inversely related to DNA methylation, while dietary folate appears to be an essential nutrient for regulating homocysteine concentrations, acting in their re-methylation to methionine [7].

Moreover, we found no association between BMI and vitamin B6 and B12 intake. Studies with children have presented similar results. Braun et al. [5] observed that the highest tertile of vitamin B6 intake was not associated with lower BMI in 2922 children (mean age 12.9 years). Unexpectedly, this study noticed higher BMI values for a greater tertile of B12 consumption, which the researchers assessed to be due to the food matrix in which this vitamin is inserted, since vitamin B12 occurs naturally in products of animal origin, which are high in protein and fat and consequently have higher caloric density [5]. Gunante et al., when investigating 1131 children enrolled in NHANES, also did not perceive a significant association between vitamin B6 intake and adiposity development [11]. In turn, a study of 128 Mexican adults, ages between 18 and 60, found no significant difference in B6 and B12 intake between individuals with and without obesity [31].

Another result that deserves attention was the possible insufficient intake of $12 \%$ for folate, $6.3 \%$ for vitamin B6, and $11.2 \%$ for B12 in our sample. A study with 357 individuals living in the urban area of the city of São Paulo observed inadequacy in folate consumption of $6 \%$ and $38 \%$ for men and women, respectively [32]. Data from Brazilian Family Budget Survey (POF 2008-2009) had presented inadequacy in vitamin B12 intake of $8.5 \%$ for men and $12.5 \%$ for women, for vitamin B6 of $17 \%$ and $31.9 \%$ for men and women (aged $20-50$ years), respectively [33]. We believe that the low prevalence of insufficient consumption of our study may have been because the population studied was academically educated, and people with higher education tend to have lower rates of inadequacy in vitamin intake [34].

Beans/lentils followed by French Bread stood out as the foods that contributed the most to folate intake, as was found in previous studies [32,35]. Despite the mandatory fortification with folic acid established by the government for wheat flour and corn [36], beans and lentils-along with other food items such as papaya, avocado, and banana-presented an important contribution in our study to folate consumption, thus indicating that folate of natural origin presents a strong participant in the ingestion of this vitamin.

The present study has limitations. First, we did not separately evaluate B-complex vitamins from fortified and naturally occurring food sources [37], although other studies have also applied a similar methodology to estimate these nutrients [12,38,39]. Second, the lack of information about DNA methylation in our population did not allow us to confirm our hypothesis that folate intake was associated with excess body weight and obesity by epigenetic mechanisms, but this analysis is predicted for future studies in the CUME project. Lastly, the use of BMI as a measure of adiposity can be limiting because this index does not establish information on the amount and location of body fat. Nevertheless, BMI is considered a good indicator of adiposity [40,41].

The quantitative FFQ validated for the Brazilian population is a strength in our study [17] since a greater consistency is guaranteed in the data obtained. In addition, the academically educated population allowed a deepening of the questionnaire questions and greater reliability in the answers. Also noteworthy is that studies with a highly educated population have shown reliable and valid results in addition to presenting greater adherence and maintenance of the population in the study [42].

\section{Conclusions}

In conclusion, higher folate intake was negatively associated with excess body weight in Brazilian graduates and postgraduates from the CUME project, and beans and lentils are important sources of this nutrient in this population. Individual and populational strategies of nutritional education 
must be promoted to incentivize food-group consumption, which has reduced in these last decades in Brazil. In addition, future studies are necessary to investigate the epigenetic mechanisms (e.g., DNA methylation) involved in the relationship between dietary folate and obesity.

Author Contributions: Conceptualization, methodology, formal analysis, investigation, data curation, writing, G.A.P., J.B., F.L.P.O., H.M.P.S., A.M.P., L.L.L. and H.H.M.H. Resources, supervision, project administration, funding acquisition, J.B., F.L.P.O., A.M.P. and H.H.M.H.

Funding: This research was funded by FAPEMIG (Minas Gerais, Brazil), grant number CDS-APQ-00424-17.

Acknowledgments: We thank the volunteers participating in the study. We are also grateful to CAPES (Ministry of Education, Brazil) for a master's scholarship granted to GA Pereira and FAPEMIG (Minas Gerais, Brazil) for the financial support for this project (CDS - APQ-00424-17). J.B., F.L.P.O., H.M.P.S., A.M.P. and H.H.M.H are CNPq research productivity fellows.

Conflicts of Interest: The authors declare no conflict of interest.

\section{References}

1. Casanello, P.; Krause, B.J.; Castro-Rodríguez, J.A.; Uauy, R. Epigenética y obesidad. Rev. Chil. Pediatría 2016, 87, 335-342. [CrossRef] [PubMed]

2. Herrera, B.M.; Keildson, S.; Lindgren, C.M. Genetics and epigenetics of obesity. Maturitas 2011, 69, 41-49. [CrossRef] [PubMed]

3. Ministério da Saúde, Secretaria de Vigilância em Saúde. Vigitel Brasil 2016: Vigilância de Fatores de Risco e Proteção Para Doenças Crônicas por Inquérito Telefônico; Ministério da Saúde: Brasilia, Brasil, 2017.

4. Milagro, F.I.; Mansego, M.L.; De Miguel, C.; Martínez, J.A. Dietary factors, epigenetic modifications and obesity outcomes: Progresses and perspectives. Mol. Asp. Med. 2013, 34, 782-812. [CrossRef] [PubMed]

5. Braun, K.V.; Voortman, T.; Kiefte-de Jong, J.C.; Jaddoe, V.W.; Hofman, A.; Franco, O.H.; van den Hooven, E.H. Dietary Intakes of folic acid and methionine in early childhood are associated with body composition at school age. J. Nutr. 2015, 145, 2123-2129. [CrossRef] [PubMed]

6. Garcia-Lacarte, M.; Milagro, F.I.; Zulet, M.A.; Martinez, J.A.; Mansego, M.L. LINE-1 methylation levels, a biomarker of weight loss in obese subjects, are influenced by dietary antioxidant capacity. Redox Rep. 2016, 21, 67-74. [CrossRef] [PubMed]

7. Mandaviya, P.R.; Stolk, L.; Heil, S.G. Homocysteine and DNA methylation: A review of animal and human literature. Mol. Genet. Metab. 2014, 113, 243-252. [CrossRef] [PubMed]

8. Glier, M.B.; Green, T.J.; Devlin, A.M. Methyl nutrients, DNA methylation, and cardiovascular disease. Mol. Nutr. Food Res. 2014, 58, 172-182. [CrossRef] [PubMed]

9. Pufulete, M.; Al-Ghnaniem, R.; Khushal, A.; Appleby, P.; Harris, N.; Gout, S.; Emery, P.W.; Sanders, T.A.B. Effect of folic acid supplementation on genomic DNA methylation in patients with colorectal adenoma. Gut 2005, 54, 648-653. [CrossRef] [PubMed]

10. Pusceddu, I.; Herrmann, M.; Kirsch, S.H.; Werner, C.; Hübner, U.; Bodis, M.; Laufs, U.; Wagenpfeil, S.; Geisel, J.; Herrmann, W. Prospective study of telomere length and LINE-1 methylation in peripheral blood cells: The role of B vitamins supplementation. Eur. J. Nutr. 2016, 55, 1863-1873. [CrossRef] [PubMed]

11. Gunanti, I.R.; Marks, G.C.; Al-Mamun, A.; Long, K.Z. Low serum vitamin B-12 and folate concentrations and low thiamin and riboflavin intakes are inversely associated with greater adiposity in Mexican American children. J. Nutr. 2014, 144, 2027-2033. [CrossRef] [PubMed]

12. Vitolo, M.R.; Canal, Q.; Campagnolo, P.D.B.; Gama, C.M. Fatores associados ao risco de ingestão insuficiente de folato entre adolescentes. J. Pediatr. 2006, 82, 121-126. [CrossRef]

13. Bird, J.K.; Ronnenberg, A.G.; Choi, S.-W.; Du, F.; Mason, J.B.; Liu, Z. obesity is associated with increased red blood cell folate despite lower dietary intakes and serum concentrations. J. Nutr. 2014, 145, 79-86. [CrossRef] [PubMed]

14. Ramos-Lopez, O.; Samblas, M.; Milagro, F.I.; Zulet, M.A.; Mansego, M.L.; Riezu-Boj, J.I.; Martinez, J.A. Association of low dietary folate intake with lower CAMKK2 gene methylation, adiposity, and insulin resistance in obese subjects. Nutr. Res. 2017, 50, 53-62. [CrossRef] [PubMed]

15. Gomes Domingos, A.L.; Miranda, A.E.D.S.; Pimenta, A.M.; Hermsdorff, H.H.M.; de Oliveira, F.L.P.; dos Santos, L.C.; Lopes, A.C.S.; Martínez González, M.Á.; Bressan, J. Cohort profile: The Cohort of Universities of Minas Gerais (CUME). Int. J. Epidemiol. 2018. [CrossRef] [PubMed] 
16. Willett, W.; Stampfer, M.J. Total energy intake: Implications for epidemiologic analyses. Am. J. Epidemiol. 1986, 124, 17-27. [CrossRef] [PubMed]

17. Henn, R.L.; Fuchs, S.C.; Moreira, L.B.; Fuchs, F.D. Development and validation of a food frequency questionnaire (FFQ-Porto Alegre) for adolescent, adult and elderly populations from Southern Brazil. Cad. Saude Publica 2010, 26, 2068-2079. [CrossRef] [PubMed]

18. Universidade Estadual de Campinas-Núcleo de Estudos e Pesquisas em Alimentação. Tabela Brasileira de Composicao de Alimentos; Universidade Estadual de Campinas-Núcleo de Estudos e Pesquisas em Alimentação: Campinas, SP, Brazil, 2011.

19. United States Department of Agriculture-Agricultural Research Service. Nutritive Value of Foods; United States Department of Agriculture: Washington, DC, USA, 2012.

20. Institute of Medicine/IOM. Dietary Reference Intakes (DRIs): Estimated Average Requirements; Institute of Medicine/IOM: Washington, DC, USA, 2002.

21. Miranda, A.E.D.S.; Ferreira, A.V.M.; Oliveira, F.L.P.; Hermsdorff, H.H.M.; Bressan, J.; Pimenta, A.M. Validation of metabolic syndrome and its self reported components in the CUME study. Reme Rev. Min. Enferm. 2017, 21, 1-7. [CrossRef]

22. World Health Organization. OBESITY: Preventing and Managing the Global Epidemic; Report of a WHO Consultation on Obesity; World Health Organization: Geneva, Switzerland, 1998; ISBN 9789241208949.

23. Organización Panamericana de La Salud. XXXVI Reunión del Comitê Asesor de Investigaciones em Salud-Encuestra Multicêntrica-Salud Beinestar y Envejecimeiento (SABE) em América Latina e el Caribe-Informe premilinar; Organización Panamericana de La Salud: Washington, DC, USA, 2002.

24. Willett, W. Nutritional Epidemiology, 2nd ed.; Oxford University Press: Oxford, UK, 1998; ISBN 9780199754038.

25. Block, G.; Dresser, C.M.; Hartman, A.M.; Carroll, M.D. Nutrient sources in the American diet: Quantitative data from the NHANES II survey. II. Macronutrients and fats. Am. J. Epidemiol. 1985, 122, 27-40. [CrossRef] [PubMed]

26. Hinnig, P.D.F.; Bergamaschi, D.P. Itens alimentares no consumo alimentar de crianças de 7 a 10 anos. Rev. Bras. Epidemiol. 2012, 15, 324-334. [CrossRef]

27. Neelakantan, N.; Whitton, C.; Seah, S.; Koh, H.; Rebello, S.A.; Lim, J.Y.; Chen, S.; Chan, M.F.; Chew, L.; van Dam, R.M. Development of a semi-quantitative food frequency questionnaire to assess the dietary intake of a multi-ethnic urban Asian population. Nutrients 2016, 8. [CrossRef] [PubMed]

28. Bradbury, K.E.; Williams, S.M.; Mann, J.I.; Brown, R.C.; Parnell, W.; Skeaff, C.M. Estimation of serum and erythrocyte folate concentrations in the New Zealand adult population within a background of voluntary folic acid fortification. J. Nutr. 2014, 144, 68-74. [CrossRef] [PubMed]

29. Piyathilake, C.J.; Badiga, S.; Alvarez, R.D.; Partridge, E.E.; Johanning, G.L. A lower degree of PBMC L1 methylation is associated with excess body weight and higher HOMA-IR in the presence of lower concentrations of plasma folate. PLoS ONE 2013, 8, e54544. [CrossRef] [PubMed]

30. Zhang, F.F.; Santella, R.M.; Wolff, M.; Kappil, M.A.; Markowitz, S.B.; Morabia, A. White blood cell global methylation and IL-6 promoter methylation in association with diet and lifestyle risk factors in a cancer-free population. Epigenetics 2012, 7, 606-614. [CrossRef] [PubMed]

31. Hernández-Guerrero, C.; Romo-Palafox, I.; Díaz-Gutiérrez, M.C.; Iturbe-García, M.; Texcahua-Salazar, A.; Pérez-Lizaur, A.B. Prevalence of metilentetrahidrofolate reductase C677T polymorphism, consumption of vitamins B6, B9, B12 and determination of lipidic hydroperoxides in obese and normal weight Mexican population. Nutr. Hosp. 2013, 28, 2142-2150. [CrossRef] [PubMed]

32. Marchioni, D.M.L.; Verly, E., Jr.; Steluti, J.; Cesar, C.L.G.; Fisberg, R.M. Ingestão de folato nos períodos pré e pós-fortificação mandatória: Estudo de base populacional em São Paulo, Brasil. Cad. Saude Publica 2013, 29, 2083-2092. [CrossRef]

33. Araujo, M.C.; Bezerra, I.N.; Barbosa, F.d.S.; Junger, W.L.; Yokoo, E.M.; Pereira, R.A.; Sichieri, R. Consumo de macronutrientes e ingestão inadequada de micronutrientes em adultos. Rev. Saude Publica 2013, 47, 177s-189s. [CrossRef] [PubMed]

34. Araujo, M.C.; Verly Junior, E.; Junger, W.L.; Sichieri, R. Independent associations of income and education with nutrient intakes in Brazilian adults: 2008-2009 National Dietary Survey. Public Health Nutr. 2014, 17, 2740-2752. [CrossRef] [PubMed] 
35. Steluti, J.; Martini, L.A.; Peters, B.S.E.; Marchioni, D.M.L. Folate, vitamin B6 and vitamin B12 in adolescence: Serum concentrations, prevalence of inadequate intakes and sources in food. J. Pediatr. 2011, 87, 43-49. [CrossRef] [PubMed]

36. Agência Nacional de Vigilância Sanitária. Resolução RDC n. ${ }^{\circ} 344$ de 13 de Dezembro de 2002. Regulamento Técnico para Fortificação das Farinhas de Trigo e das Farinhas de Milho com Ferro e Ácido Fólico; Agência Nacional de Vigilância Sanitária: Brasília, DF, Brazil, 2002.

37. Huang, T.; Zheng, Y.; Qi, Q.; Xu, M.; Ley, S.H.; Li, Y.; Kang, J.H.; Wiggs, J.; Pasquale, L.R.; Chan, A.T.; et al. DNA Methylation Variants at HIF3A Locus, B-Vitamin Intake, and Long-term Weight Change: Gene-Diet Interactions in Two, U.S. Cohorts. Diabetes 2015, 64, 3146-3154. [CrossRef] [PubMed]

38. Liu, R.; Mi, B.; Zhao, Y.; Li, Q.; Yan, H.; Dang, S. Effect of B vitamins from diet on hypertension. Arch. Med. Res. 2017, 48, 187-194. [CrossRef] [PubMed]

39. Seppälä, J.; Koponen, H.; Kautiainen, H.; Eriksson, J.G.; Kampman, O.; Männistö, S.; Mäntyselkä, P.; Oksa, H.; Ovaskainen, Y.; Viikki, M.; et al. Association between folate intake and melancholic depressive symptoms. A Finnish population-based study. J. Affect. Disord. 2012, 138, 473-478. [CrossRef]

40. Lear, S.A.; Humphries, K.H.; Kohli, S.; Birmingham, C.L. The use of BMI and waist circumference as surrogates of body fat differs by ethnicity. Obesity 2007, 15, 2817-2824. [CrossRef] [PubMed]

41. Ranasinghe, C.; Gamage, P.; Katulanda, P.; Andraweera, N.; Thilakarathne, S.; Tharanga, P. Relationship between body mass index (BMI) and body fat percentage, estimated by bioelectrical impedance, in a group of Sri Lankan adults: A cross sectional study. BMC Public Health 2013, 13, 797. [CrossRef] [PubMed]

42. Seguí-Gómez, M.; de la Fuente, C.; Vázquez, Z.; de Irala, J.; Martínez-González, M.A. Cohort profile: The "Seguimiento Universidad de Navarra" (SUN) study. Int. J. Epidemiol. 2006, 35, 1417-1422. [CrossRef] [PubMed]

(C) 2019 by the authors. Licensee MDPI, Basel, Switzerland. This article is an open access article distributed under the terms and conditions of the Creative Commons Attribution (CC BY) license (http://creativecommons.org/licenses/by/4.0/). 